Supporting Information

\title{
Enabling Direct Protein Detection in a Drop of Whole Blood with an "On- Strip" Plasma Separation Unit in a Paper-Based Lateral Flow Strip
}

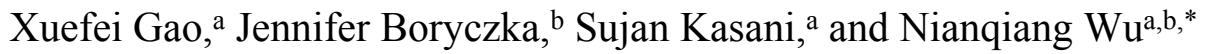

aDepartment of Mechanical and Aerospace Engineering, West Virginia University, Morgantown, West Virginia 26506-6106, United States

bDepartment of Chemical Engineering, University of Massachusetts Amherst, Amherst, MA 01003-9303, USA

*Corresponding author: Tel: +1-413-545-6175, E-mail: nianqiangwu@umass.edu 


\section{Table of Contents}

Table S1. Abbreviations and their corresponding full names used in this article.

Table S2. Comparison of the present device with those reported in the literature

Figure S1. Optical image of the side-view of a plasma separation unit, consisting of layer-1, layer-2, layer-3 and a conjugate pad.

Figure S2. Schematic synthesis procedure for the detection antibody-linked to the SERS probes.

Figure S3. Schematic illustration and the corresponding optical image of a lateral flow test strip with an integrated plasma separation unit after $30 \mu \mathrm{L}$ of whole blood is separated.

Figure S4. Definitions of $\mathrm{ASE}_{12}$ and $\mathrm{ASE}_{13}$ for a one-layer filter.

Figure S5. Histogram of the SERS peak intensity at $1084 \mathrm{~cm}^{-1}$ of the PLFSs after storage for 1, 7, 14 and 30 day, respectively.

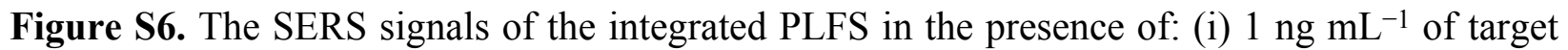

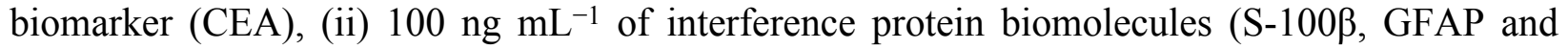
$\mathrm{NSE}$ ), and (iii) $0 \mathrm{ng} \mathrm{mL}^{-1}$ of protein molecules in the control sample.

\section{References}


Table S1. Abbreviations and their corresponding full names used in this article.

\begin{tabular}{cl}
\hline Abbreviations & \multicolumn{1}{c}{ Full Name } \\
\hline ASE & Apparent Separation Efficiency \\
\hline CEA & Carcinoembryonic Antigen \\
\hline PLFS & Paper-based Lateral Flow Strip \\
\hline PSU & Plasma Separation Unit \\
\hline SERS & Surface-Enhanced Raman Scattering \\
\hline
\end{tabular}


Table S2 Comparison of the present device with those reported in the literature

\begin{tabular}{|c|c|c|c|c|c|}
\hline Analyte & Label & $\begin{array}{c}\text { Sample } \\
\text { Matrices }\end{array}$ & LOD & Linear Range & Ref. \\
\hline CEA & $\begin{array}{l}\text { Au nanostar@Raman } \\
\text { reporter@silica } \\
\text { (sandwich SERS } \\
\text { nanoparticles) }\end{array}$ & $\begin{array}{l}\text { Whole } \\
\text { Blood }\end{array}$ & $\begin{array}{l}1 \mathrm{ng} / \mathrm{mL} \text { in } \\
\text { whole blood }\end{array}$ & $\begin{array}{l}5.0 \mathrm{ng} / \mathrm{mL} \text { to } \\
100.0 \mathrm{ng} / \mathrm{mL} \text { in } \\
\text { whole blood }\end{array}$ & $\begin{array}{l}\text { This } \\
\text { work }\end{array}$ \\
\hline Abrin & $\begin{array}{l}\mathrm{Au} \\
\text { nanosphere@Raman } \\
\text { reporter }\end{array}$ & Buffer & $\begin{array}{l}0.1 \mathrm{ng} / \mathrm{mL} \text { in } \\
\text { buffer }\end{array}$ & $\begin{array}{l}0.1 \mathrm{ng} / \mathrm{mL} \text { to } 1 \\
\mu \mathrm{g} / \mathrm{mL}\end{array}$ & $\operatorname{Ref}^{(2)}$ \\
\hline $\operatorname{IgG}$ & $\begin{array}{l}\text { Au nanostar@Raman } \\
\text { reporter@silica } \\
\text { (sandwich SERS } \\
\text { nanoparticles) }\end{array}$ & $\begin{array}{l}\text { Buffer and } \\
\text { Blood } \\
\text { Plasma }\end{array}$ & $\begin{array}{l}\text { (i) } 0.02 \mathrm{ng} / \mathrm{mL} \\
\text { in buffer } \\
\text { (ii) } 0.08 \\
\mathrm{ng} / \mathrm{mL} \text { in } 10 \% \\
\text { of blood } \\
\text { plasma }\end{array}$ & $\begin{array}{l}\text { (i) } 0.5 \mathrm{ng} / \mathrm{mL} \text { to } \\
0.1 \mathrm{mg} / \mathrm{mL} \text { in } \\
\text { buffer } \\
\text { (ii) } 1.0 \mathrm{ng} / \mathrm{mL} \text { to } \\
0.05 \mathrm{mg} / \mathrm{mL} \text { in } \\
10 \% \text { of blood } \\
\text { plasma }\end{array}$ & $\operatorname{Ref}^{(1)}$ \\
\hline CEA & $\begin{array}{l}\text { Fluorescent dyes/ } \\
\text { Au Nanoparticles }\end{array}$ & $\begin{array}{l}\text { Buffer and } \\
\text { Serum }\end{array}$ & $\begin{array}{l}\text { (i) } 0.1 \mathrm{ng} / \mathrm{mL} \\
\text { in buffer } \\
\text { (ii) Capable of } \\
\text { detecting } 10 \\
\mathrm{ng} / \mathrm{mL} \text { of } \\
\text { CEA in serum }\end{array}$ & $\begin{array}{l}5 \mathrm{ng} / \mathrm{mL} \text { to } 80 \\
\mathrm{ng} / \mathrm{mL} \text { in buffer }\end{array}$ & $\operatorname{Ref}^{(3)}$ \\
\hline $\begin{array}{l}\text { HSA and } \\
\text { GA }\end{array}$ & Au nanosphere & Serum & $\begin{array}{l}\text { (i) HAS in } \\
\text { serum: } 1 \\
\mathrm{ng} / \mathrm{mL} \\
\text { (ii) GA in } \\
\text { serum: } 0.5 \\
\mu \mathrm{g} / \mathrm{mL}\end{array}$ & $\begin{array}{l}\text { (i) } \mathrm{HAS}: 1 \mathrm{ng} / \mathrm{mL} \\
\text { to } 1 \mathrm{mg} / \mathrm{mL} \\
\text { (ii) } \mathrm{GA}: 0.5 \\
\mu \mathrm{g} / \mathrm{mL} \text { to } 3.6 \\
\mathrm{mg} / \mathrm{mL}\end{array}$ & $\operatorname{Ref}^{(4)}$ \\
\hline $\begin{array}{l}1 \alpha- \\
\text { fetoprotein }\end{array}$ & Au nanosphere & Serum & $20 \mathrm{ng} / \mathrm{mL}$ & $\begin{array}{l}\text { Detection range: } \\
56.2 \mathrm{ng} / \mathrm{mL} \text { to } \\
806.2 \mathrm{ng} / \mathrm{mL}\end{array}$ & $\operatorname{Ref}(5)$ \\
\hline Bilirubin & Au nanosphere & $\begin{array}{l}\text { Whole } \\
\text { Blood }\end{array}$ & $12 \mu \mathrm{g} / \mathrm{mL}$ & $\begin{array}{l}12 \mu \mathrm{g} / \mathrm{mL} \text { to } 0.2 \\
\mathrm{mg} / \mathrm{mL}\end{array}$ & $\operatorname{Ref}^{(6)}$ \\
\hline
\end{tabular}




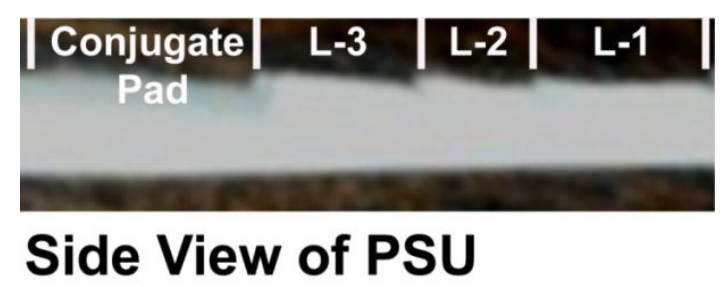

Figure S1. Optical image of the side-view of a plasma separation unit, consisting of layer-1, layer-2, layer-3 and a conjugate pad. 


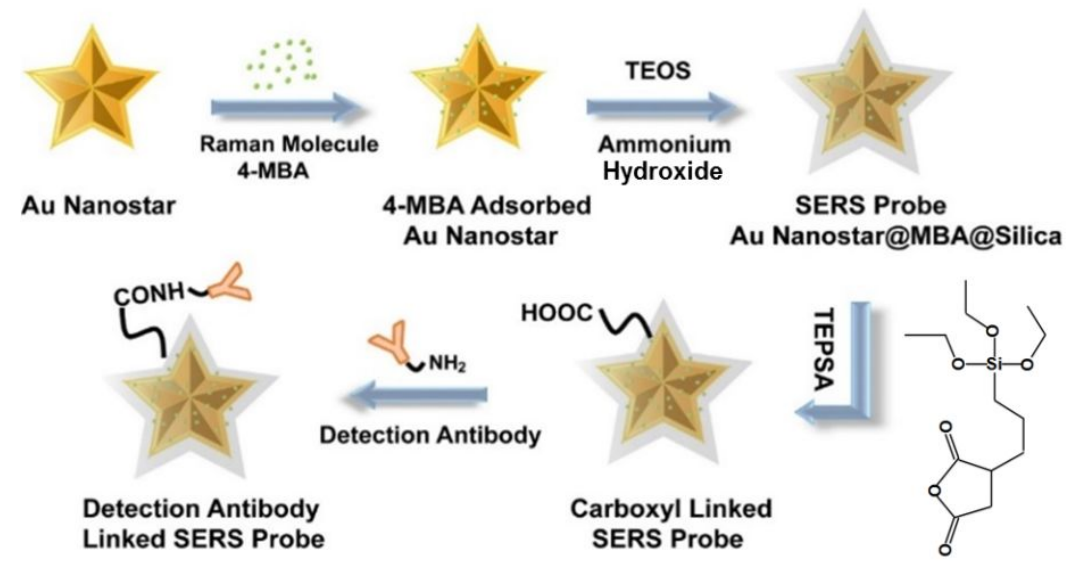

Figure S2. Schematic synthesis procedure for the detection antibody-linked to the SERS probes.

Preparation of surface enhanced Raman scattering (SERS) probes

The antibody functionalized SERS probes were prepared according to our paper. ${ }^{(1)}$ The schematic illustration is presented in Figure S2. Briefly, the sandwich typed SERS probes were synthesized by adding $20 \mu \mathrm{L}$ of $250 \mu \mathrm{M}$ 4-MBA into $5 \mathrm{~mL}$ of Au nanostar suspension. Then, 200 $\mu \mathrm{L}$ of solution of $1 \%(\mathrm{v} / \mathrm{v})$ TEOS in ethanol was added into the mixture solution and stirred for 20 min. Subsequently, $15 \mu \mathrm{L}$ of ammonium hydroxide solution $(28 \%)$ was added into the mixture. After the SERS probes were formed, the resulting solutions were centrifuged and dissolved in $500 \mu \mathrm{L}$ of ethanol. TEPSA $(20 \mu \mathrm{L})$ was added to the SERS probe solution and then incubated overnight to achieve the carboxyl-group terminated SERS probes. Subsequently a PBS buffer solution containing $50 \mathrm{mM}$ NHS and $200 \mathrm{mM}$ EDC was added into the solution, and then incubated for $1 \mathrm{~h}$, followed with addition of $100 \mu \mathrm{L}$ of $1.0 \mathrm{mg} \mathrm{mL}^{-1}$ detection antibody. After the solution was mixed well, the mixture was incubated overnight. Next, the mixture was centrifuged and washed with a PBS buffer three times to remove excessive free antibody. The resulting SERS probe conjugates were re-dispersed and stored in $500 \mu \mathrm{L}$ of eluent buffer $(20 \mathrm{nM}$ $\mathrm{Na}_{3} \mathrm{PO}_{4} \cdot 12 \mathrm{H}_{2} \mathrm{O}$ aqueous solution containing 5 wt.\% BSA, 0.25 vol.\% Tween 20 , and 10 wt.\% sucrose) solution for future use. The morphology and corresponding characterization can be found in our previous report. ${ }^{[\mathrm{S} 1]}$ 


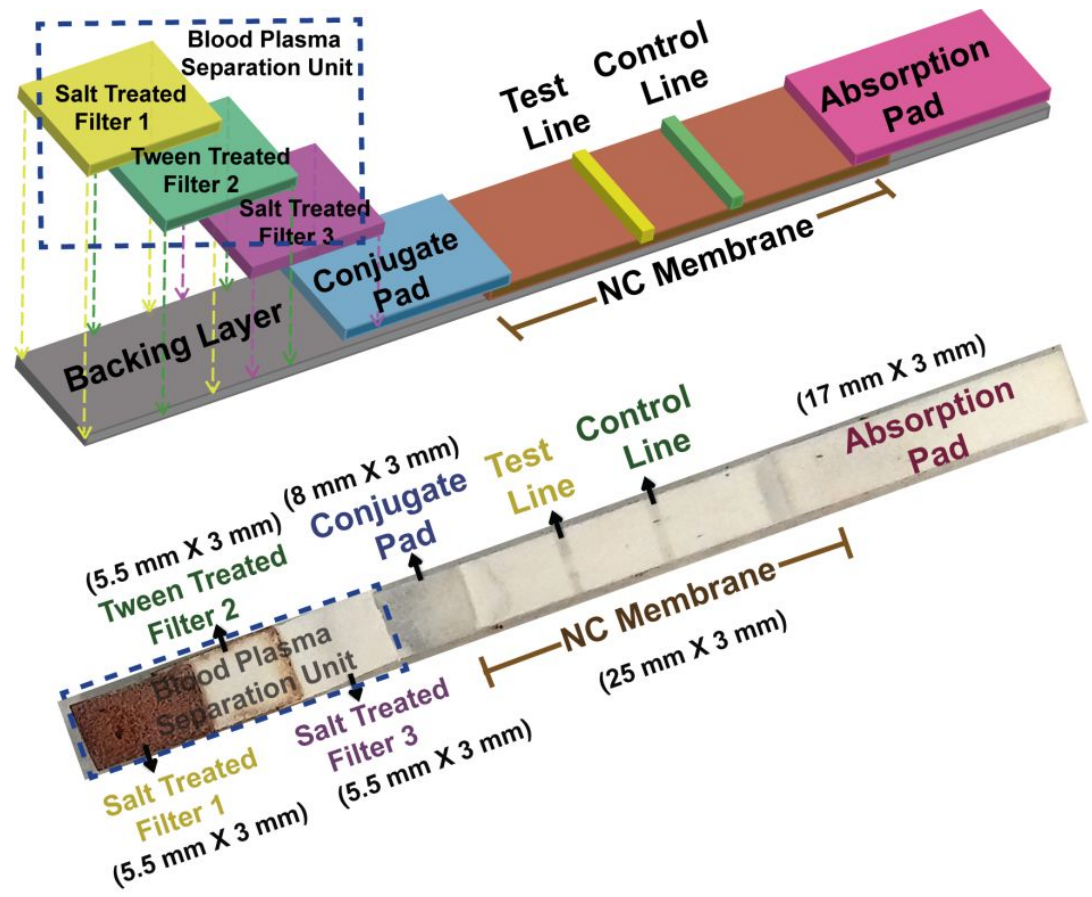

Figure S3. Schematic illustration and the corresponding optical image of a paper lateral flow test strip with an integrated plasma separation unit after $30 \mu \mathrm{L}$ of whole blood is separated.

Blood plasma separation unit (PSU): The PSU is used to selectively trap the red blood cells inside and separate the target biomarker from whole blood to plasma. A PSU consists of three stacked blood filtration membranes (Vivid ${ }^{\mathrm{TM}}$ GR, Pall Life Sciences), which are functionalized with salt (sodium chloride), surfactant (TWEEN 20) and salt (sodium chloride), respectively. The first and third layers of membranes with salt functionalization are employed to aggregate and intercept the red blood cells in their pores and fiber networks. The surfactant immobilization on the second layer of the membrane is used to accelerate separation of plasma to pass through the whole PSU assembly. Each layer of the membrane is cut with a dimension of $5.5 \mathrm{~mm} \times 3$ $\mathrm{mm}$ and then laminated on the plastic backing with an overlap of $1.5 \mathrm{~mm}$.

Conjugate pad: The conjugate pad is made of glass fiber (GFCP000800, Millipore). The glass fibers can easily adsorb/store the detection antibody linked to the nanoparticles on its fiber network under the dry condition. It can also facilely release the antibody linked to the nanoparticles with low residue on the fiber network in the presence of flowing fluids. The dimension of the conjugate pad is $8 \mathrm{~mm} \times 3 \mathrm{~mm}$.

Nitrocellulose membrane: The nitrocellulose membrane is the main component that transports the fluid in the whole device. It has several functions: (i) it allows for the capture antibody and 
the secondary antibody to be anchored stably on its surface on the detection zone and the control zone, respectively; (ii) it transports the detection antibody-SERS nanoparticle complex by capillary force from the conjugate pad to the test area; and (iii) it acts as the substrate for signal acquisition from the test area. Two kinds of nitrocellulose membranes (RK12312 Membrane and RK13464; Millipore) with different pore sizes are employed in the current study to optimize the flow rate and the test line, which substantially affect the signal intensity, as well as the detection sensitivity of the device. The dimension of the nitrocellulose membrane is $22 \mathrm{~mm} \times 3 \mathrm{~mm}$.

Absorbent pad: The absorption pad is made from cellulose fiber sample pads (CFSP001700, Millipore). The function of the absorption pad is used to adsorb the excess fluid from the device while acting as a sink. The capillary force draws fluid through the nitrocellulose membrane from the blood plasma separation unit into the absorption pad. The dimension of the absorption pad used in this study is $17 \mathrm{~mm} \times 3 \mathrm{~mm}$.

Adhesive backing layer: The adhesive backing layer (HF000MC100, Millipore) is used to orderly laminate each component of the paper device, including the plasma separation unit, the conjugate pad, the nitrocellulose membrane and the absorbent pad. Each component is overlapped by $2 \mathrm{~mm}$ to ensure the migration of liquid throughout the paper device. The dimension of the adhesive backing layer for each paper device is $60 \mathrm{~mm} \times 3 \mathrm{~mm}$. 


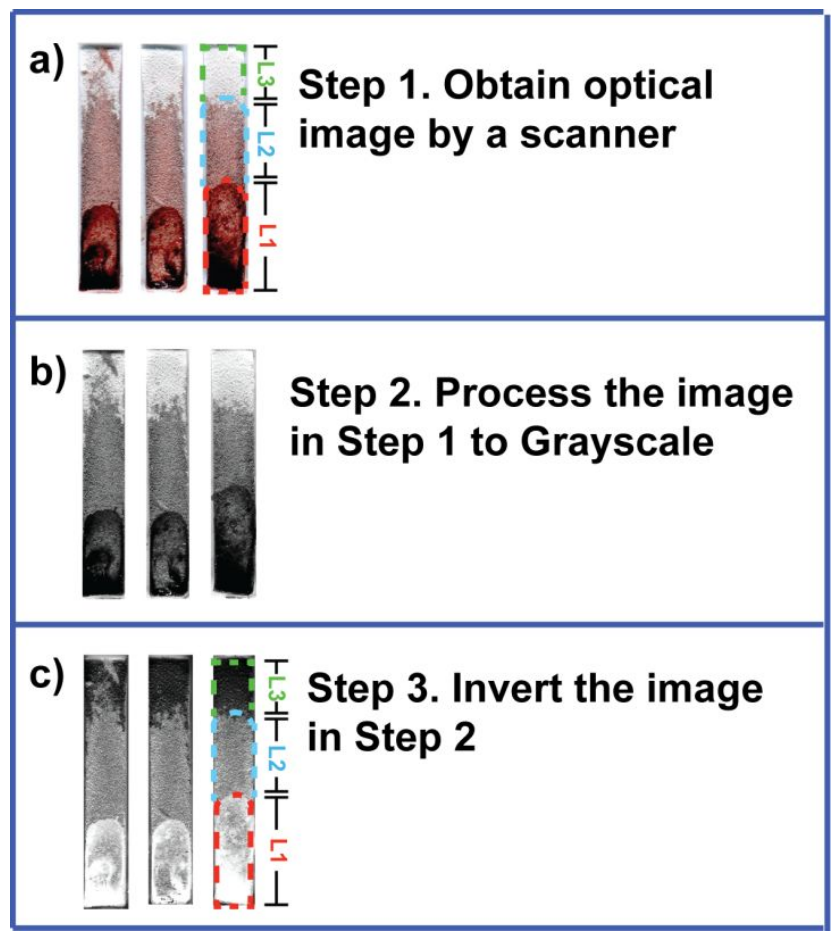

Figure S4. Definitions of $\mathrm{ASE}_{12}$ and $\mathrm{ASE}_{13}$ for a one-layer filter. (a) one-layer filter treated with salt (0.154 M), (b) grayscale of one-layer filter treated with salt, (c) inverted image of one-layer filter treated with salt.

The definition of the $\mathrm{ASE}_{12}$ and $\mathrm{ASE}_{13}$ for a one-layer PSU is similar to that for the threelayer PSU. The $\mathrm{ASE}_{12}$ and $\mathrm{ASE}_{13}$ for a one-layer PSU are used to evaluate the separation performance on the PSU. Specifically, the optical images of the one-layer PSU were acquired by a scanner and then processed and inverted by Adobe Photoshop software from a grayscale blackwhite model to a white-black model. The resulting images with the white-black model were employed to calculate the $\mathrm{ASE}_{12}$ and $\mathrm{ASE}_{13}$ of the one-layer PSU using the ImageJ software. The image processing steps are illustrated in Figure S4. For a one-layer PSU, the $\mathrm{ASE}_{12}$ and $\mathrm{ASE}_{13}$ are defined as follows:

$$
\begin{aligned}
& A S E_{12}=\left(I_{\text {layer } 1}-I_{\text {layer } 2}\right) / I_{\text {layer } 1} \\
& A S E_{13}=\left(I_{\text {layer } 1}-I_{\text {layer } 3}\right) / I_{\text {layer } 1}
\end{aligned}
$$

where I represents the grayscale intensity of the filter membrane in the optical image at the white-black model (Figure S4c) divided by the marked region area of the corresponding blood 
filtration membrane. For example, the $I_{\text {layer } 1}$ in the above equation indicates the grayscale intensity of the filter layer 1 with the white-black model divided by the area of Layer 1 (marked by red dashed lines). The "layers" on the one-layer PSU are estimated according to the hierarchical blood components retained on the filter surface. As shown in Figure S4a and S4c, Layer 1 is labeled with red dashed lines, which comprises of the most of the RBCs from the whole blood sample and exhibits the darkest red color on the filter surface. Layer 3 is labeled with green dashed lines, which consists of the separated plasma from the whole blood sample and shows the lightest pink color. Layer 2 is the area between Layer 1 and Layer 3, which is labeled with the blue dashed lines. 


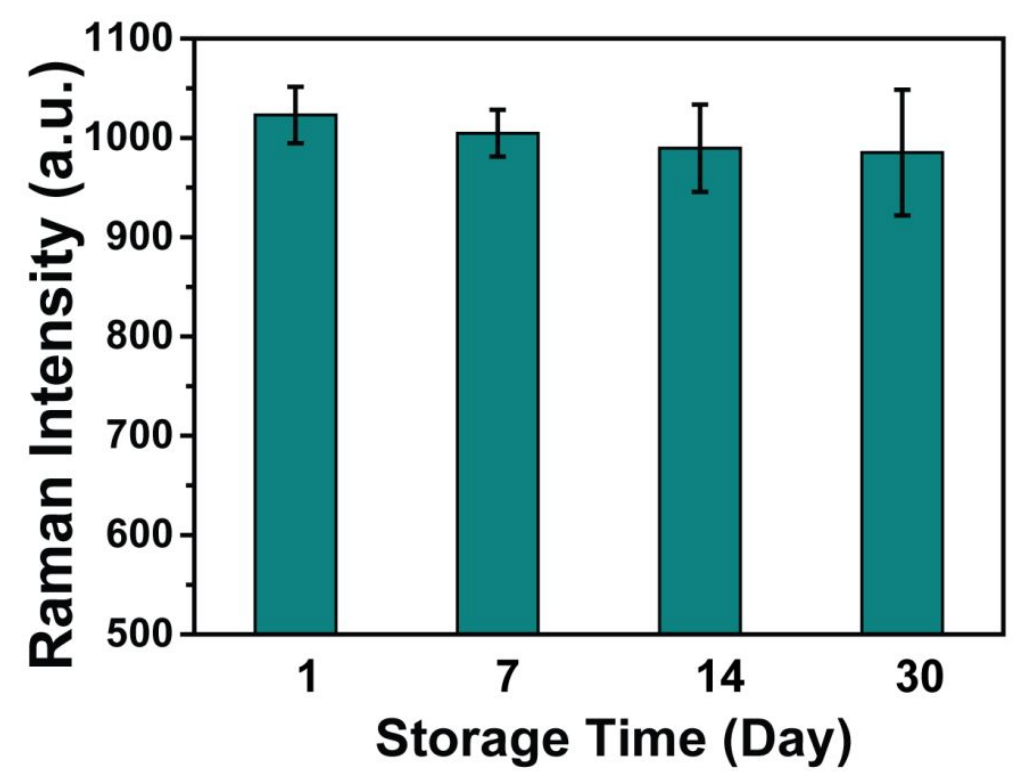

Figure S5. Histogram of the SERS peak intensity at $1084 \mathrm{~cm}^{-1}$ of the PLFSs after storage for 1, 7, 14 and 30 day, respectively. 


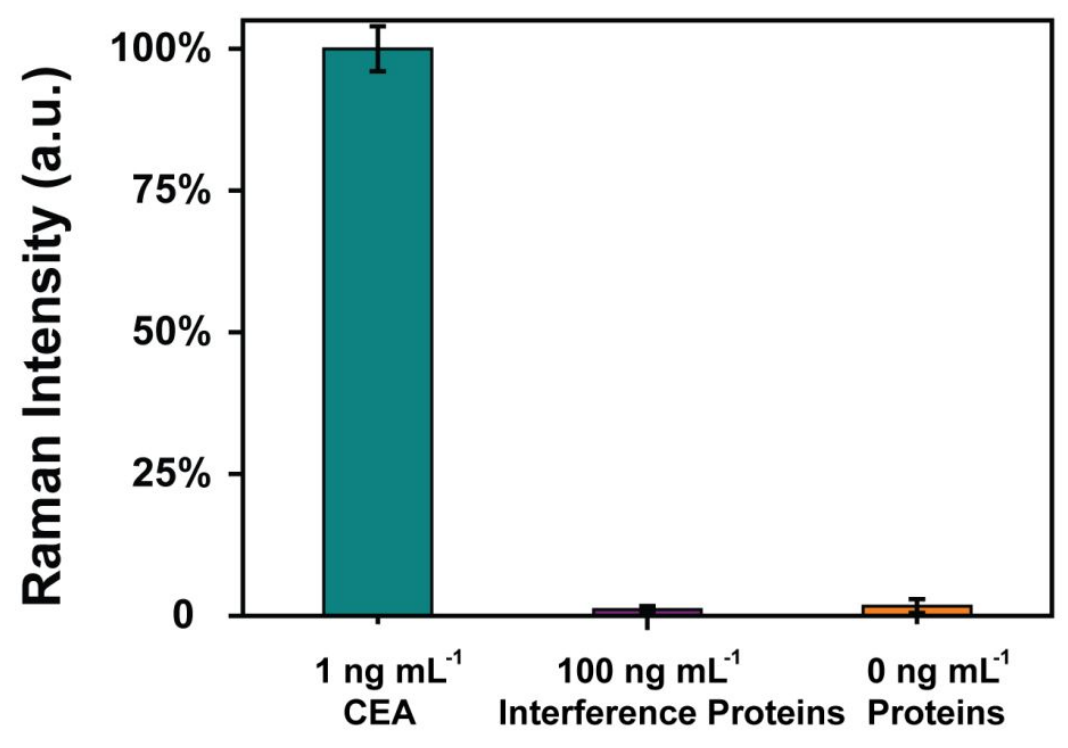

Figure S6. The SERS signals of the integrated PLFS in the presence of: (i) $1 \mathrm{ng} \mathrm{mL}-1$ of target biomarker (CEA), (ii) $100 \mathrm{ng} \mathrm{mL}^{-1}$ of interference protein biomolecules (S-100 $\beta$, GFAP and NSE), and (iii) $0 \mathrm{ng} \mathrm{mL}^{-1}$ of protein molecules in the control sample. 


\section{References}

(1) X. Gao, P. Zheng, S. Kasani, S. Wu, F. Yang, S. Lewis, S. Nayeem, E. B. Engler-Chiurazzi, J. G. Wigginton and J. W. Simpkins, Analytical Chemistry, 2017, 89, 10104-10110.

(2) H. Yang, M. Deng, S. Ga, S. Chen, L. Kang, J. Wang, W. Xin, T. Zhang, Z. You and Y. An, Nanoscale Research Letters, 2014, 9, 138.

(3) J. Wang, F. Cao, S. He, Y. Xia, X. Liu, W. Jiang, Y. Yu, H. Zhang and W. Chen, Talanta, 2018, 176, 444-449.

(4) H. Ki, J. Oh, G.-R. Han and M.-G. Kim, Lab on a Chip, 2020. 20, 844-851.

(5) Y. Zhang, J. Bai and J. Y. Ying, Lab on a Chip, 2015, 15, 1465-1471.

(6) W. Tan, L. Zhang, J. C. Doery and W. Shen, Lab on a Chip, 2020, 20, 394-404. 